\title{
Influence of Mulching and Graded Fertility Levels on Microbial Population, Growth and Productivity of Potato (Solanum tuberosum L.)
}

\author{
Dhiman Mukherjee*
}

Department of Agronomy, Bidhan Chandra Krishi Viswavidyalaya, Mohanpur-741 252, Nadia, West Bengal, India

*Corresponding author

\begin{tabular}{|l|}
\hline Ke y w o r d s \\
CGR, Fertility \\
levels, Microbial \\
population, Mulch, \\
Potato yield.
\end{tabular}

\section{Keywords}

CGR, Fertility levels, Microbial population, Mulch, Article Info

Accepted: Available Online: 10 October 2017

\section{A B S T R A C T}

Potato is one of the most important and widely cultivated rabi crops of India. India ranks third in area and fourth in total potato production of the world. The increase in potato production in India has been very impressive by about $900 \%$ during the last 50 years. Good productivity become under question due to poor moisture conservation and nutrient management practices. Present investigation was undertaken during rabi seasons of 20152016 and 2016-17 under the umbrella of Bidhan Chandra Krishi Viswavidayalaya. The experiment was laid down in split plot design, comprising different mulching treatments in main plot (viz. no mulch, stubble, rice straw and FYM mulch) and five different fertility levels (viz. 50,75,100,125 and $150 \%$ RDF) were allocated in subplot with three replications. The CGR per unit area increased gradually from 50 days reaching the maximum between 60-70 days. There was a reduction in the rate of CGR at 80 DAP. With various main plot treatments, mulches application produced significant response amongst different plots. Significantly maximum weight of tubers per plant was obtained with rice straw mulch followed by stubble mulching, and showed parity amongst them. Highest weight of tuber was recorded with $125 \%$ NPK and showed parity with $100 \%$ RDF and statistically better to all other options. Use of rice straw mulch, recorded the highest tuber yield $(31.17 \mathrm{t} / \mathrm{ha})$ though it remained statistically at par with stubble mulching practices (30.68 t/ha), and significantly better to all other treatments. The increasing levels of fertilizer levels from 50 to $125 \% \mathrm{RDF}$, gradually and significantly increased the yield. The maximum yield (33.08 t/ha) was registered with $125 \%$ RDF that remained statistically at par only with $100 \%$ RDF and significantly better to other subplot treatments. Per rupee investment revealed that, higher B: $\mathrm{C}$ ratio (2.06) and net return ( $₹ 60,512 / \mathrm{ha}$ ) found with rice straw along with $125 \%$ fertility levels.

\section{Introduction}

Potato (Solonum tuberosum) is an important crop of the world. It can produce 3-4 time more yield per unit area as compared to cereals. The average yield of potato crop is low in India as compared to advanced countries of the world. Potatoes are an economical food; they provide a source of low cost energy to the human diet.
The reasons for low yield are many but unavailability of quality seed, weed crop competition and inadequate and injudicious use of fertilizer are of prime importance. Wider spacing, frequent irrigations and liberal use of manures and fertilizers provide favorable conditions for an early start of weeds well before the emergence of potato 
plant. Mulching plays an important role in ameliorating soil and environmental stresses of potato crops along with good weed control measures. But for non- tropical crops such as potato, the beneficial effects are somewhat obscured by the incompatibility of mulching with existing soil and crop management practices. Potato is a plant that consumes large quantities of nutrients and capitalizes better mineral and organic fertilizers applied rationally. Supply of nutrients plays an important role in growth and yield. Potato yield is influenced by both quantitatively and qualitatively. Rational fertilization aims at balancing the amount of nutrients through fertilizers, taking into account the contribution of soil (Mukherjee, 2017). Excessive application rates of nitrogen and potassium, along with excessive soil levels of eithers nutrient, may reduce tuber solids. Potato crop has strict requirement for a balanced fertilization management, without which yield and quality of tubers are diminished. Nitrogen is the one most often limiting for potato growth; application of fertilizer $\mathrm{N}$ is necessary to ensure profitable potato production and, in general, $\mathrm{N}$ application increases the proportion of largersized tubers (Zebarth and Rosen, 2007). Nitrogen is an essential constituent of protein and chlorophyll, where phosphorus fertilization contributes to early crop development and tuberization and enhances tuber maturation, whereas potassium influences both yield and tuber quality and also enhances plant resistance to withstand stress against drought and frost (Mukherjee, 2015). Potassium deficiencies reduce the yield, size and quality of the potato crop (Mikkelsen, 2006). Soil micro-organisms are immersed in a framework of interactions known to affect plant fitness and soil quality. The soil micro-organisms act as sink and source of nutrients as these are organic decomposers and hence provide more nutrients to plants. Soil micro-organisms are also capable of promoting plant growth through different mechanisms, such as biological nitrogen fixation (BNF), phytohormone production, phosphate solubilization and siderophore production. They are also known to participate in many important ecosystem processes such as the biological control of plant pathogens, nutrient cycling, and/ or seedling growth (Zahir et al., 2004). Soil micro-organisms are involved in fundamental activities that ensure the stability and productivity of both agricultural systems and natural ecosystems (Mukherjee, 2015). Soil micro-organisms are greatly influenced by the modern agricultural practices like mulching and fertilizer nitrogen fertilization. The nutrients in mulch and $\mathrm{N}$-fertilizer have to pass through the gut of the microbes in the soil. The cultivation method (bare soil and mulch) introduced differences in the initial counts, evolution and tolerance to refrigeration temperatures for some of the microbial populations (Ponce et al., 2008). Mulching increased soil microbial flora and helped in maintaining favorable soil temperature for microbial growth (Aguero $e t$ al., 2008). With the introduction of high yielding crop varieties having high water and fertilizer needs, farmers are confronted with the challenge of providing crops with optimal quantities of water and nutrients in the most effective manners so as to have high yield. Field experiment was, therefore, conducted to explore this possibility and to recommend use of appropriate mulching option with optimum dose of fertilizer its proper application on potato.

\section{Materials and Methods}

A field study was undertaken during rabi seasons of 2015-2016 and 2016-17 at Kalyni, AB Block Seed Farm, W.B. on sandy loam soil (Gangetic Alluvium) with $\mathrm{pH} 7.1$, having available N, P and $\mathrm{K}$ 247.53, 20.16 and $212.32 \mathrm{~kg} \mathrm{ha}^{-1}$, respectively. Meteoroglogical 
data during the cropping seasons revealed that average maximum and minimum temperatures were 31.5 and $16.3^{\circ} \mathrm{C}$, respectively. Average relative humidity prevailed between 84.3 (maximum) and $53.6 \%$ (minimum). The rainfall during the experimental period (November to March) was $33.2 \mathrm{~mm}$ (5 rainy day) and $24.6 \mathrm{~mm}$ (3 rainy days) in 2015-16 and 2016-17, respectively. The experiment was laid down in split plot design, comprising different mulching treatments in main plot (viz. no mulch, stubble, rice straw and FYM mulch) and five different fertility levels (viz. $50,75,100,125$ and $150 \%$ RDF) were allocated in subplot with three replications. Whole tubers of Kufri Jyoti (duration 90-100 days) were planted in the last week of November, in rows $60 \mathrm{~cm}$ apart keeping a distance of $20 \mathrm{~cm}$ between the plants and dehaulmed in the second week of February, during both the years.

Recommended doses of fertilizer mainly comprised with $200 \mathrm{~kg} \mathrm{~N}, 150 \mathrm{Kg} \mathrm{P}_{2} \mathrm{O}_{5}$ and $150 \mathrm{~kg} \mathrm{~K} \mathrm{~K}_{2} \mathrm{O} / \mathrm{ha}$ was applied through urea, single super phosphate and muriate of potash. Half of $\mathrm{N}(100 \mathrm{~kg} / \mathrm{ha})$ and full dose $\mathrm{P}_{2} \mathrm{O}_{5}$ and $\mathrm{K}_{2} \mathrm{O}$ were placed in bands below seed tubers at the time of planting and remaining nitrogen was applied at the time of earthing up (30 DAP). The crop was raised using all the recommended cultural practices except mulching treatments. Different mulching materials were placed one week after planting. Different mulching materials were applied immediately after planting @ 600 $\mathrm{q} / \mathrm{ha}$ of farm yard manure, $150 \mathrm{q} / \mathrm{ha}$ of rice straw and $150 \mathrm{q} / \mathrm{ha}$ of stubble mulch (grasses and twig etc.). After 45 days of planting, the mulches were removed and reapplied immediately after the completion of earthing and top dressing of $\mathrm{N}$. The soil sampling was done by collecting rhizospheric soil $(0-15 \mathrm{~cm})$ from four randomly selected points in each plot. The enumeration of different microorganisms was done using standard spread plate technique. The bacterial count was enumerated on nutrient agar (Wright, 1933) media plates, fungi enumerated on glucose yeast extract (GYE) media, diazotrophs enumerated on Burk's agar and PGPR's on King's B media. Microbial count was made 30 days after planting (DAP). At initial stage of experiment, the initial bacterial count, diazotrophs count, PGPR's and fungus count was found to be $8.11 \times 10^{5}, 5 \times 10^{5}, 14 \times 10^{4}$ and $13 \times 10^{3} \mathrm{cfu} / \mathrm{g}$ of soil, respectively. Data of yield attributes were recorded at fifteen days interval starting from $50 \mathrm{DAP}$ and growth characteristics were measured at 90 DAP. Potato crop was harvested at full maturity (100 DAP). The net income generated by the crop was the amount of money left when cultivation cost is subtracted from total income. The total cost of cultivation includes cost of all the inputs like potato seed, fertilizers, herbicides, fungicides, pesticides, labour wages and other. The benefit: cost ratio was calculated by dividing the total income with total cost of cultivation. Statistical analysis and soil analysis were done as per procedures suggested by Panse and Sukhatme (1995) and Jackson (1967) respectively.

\section{Results and Discussion}

\section{Dry matter accumulation}

The use of mulches imparted a significant effect on dry matter (DM) production at all the successive growth stages of the crop (Table1). The dry matter yield increased with advancement of the age of the crop till maturity, however, the rate of increase was rapid up to 70 DAP and thereafter it slowed down. Pooled data indicate that application of different mulches maintained their distinct superiority to control (no mulch), and rice straw mulch accounted for the highest value at all the growth stages and the effect was significantly superior to rest of the mulching practices except 70 DAP with stubble 
mulching, where they remained at par. This corroborate with the earlier finding of Uniyal and Mishra (2003) Different fertility levels revealed that, $15 \%$ RDF gave significantly higher dry matter production at initial stage (50 and 60 DAP), however at latter stage more dry matter production observed with the 100 and $125 \%$ RDF. At 45 and 60 DAP maximum dry matter production registered with the $150 \%$ RDF and showed parity with the 125 and $100 \%$ RDF only at 50 DAP and significantly better to other treatments. At 70 and 80 DAP, maximum dry matter production registered with the $125 \% \quad \mathrm{RDF}$ and significantly better to other treatments of subplots. The increase in DM production by higher fertility levels might be due to more nutrients available during the crop period.

\section{Crop growth rate}

Crop growth rate (CGR) vary significantly with the different mulching and fertility levels at different growth stages of the crop till harvest (Table 1). The CGR per unit area increased gradually from 50 days reaching the maximum between 60-70 days. There was a reduction in the rate of CGR at 80 DAP. Pooled data show that in the early stages of growth (50-60 DAP), stubbles mulch produced the highest CGR $\left(13.70 \mathrm{~g} / \mathrm{m}^{2} /\right.$ day $)$ and significantly better to all other main plot treatments. During the pick growth stages of the crop (60-70 DAP) the highest CGR was obtained with FYM mulch $\left(21.29 \mathrm{~g} / \mathrm{m}^{2} /\right.$ day $)$, which remained statistically at par with rice straw and stubble mulching. The rapid increase in fresh weight of leaves and stems resulted in higher CGR at this stage. Differential response of mulches on different treatment setup and plant characters necessitated to find out the relationship between them and causes of influences of the mulches. During 70-80 DAP, rice straw mulch application recorded the highest CGR and remained at par with use of FYM as mulching materials and significantly better to other options. Maximum, CGR at 50-60 DAP produced with $75 \%$ RDF and statistically better to all other options of subplot treatments. Further at 60-70 DAP, highest CGR registered with the $100 \%$ RDF and showed parity with all the fertility levels except $75 \%$ RDF. Further, observation of table 1 , revealed that, at 70-80 DAP more CGR found with the $125 \% \mathrm{RDF}$ and at par with all other treatments except $100 \%$ RDF. Plant height of potato at harvest with rice straw and stubble mulch treatment was at par and significantly higher than no mulch and other treatments (Table 1). This could be attributed to faster emergence facilitated by higher temperature and moisture content of the soil due to mulching. Further, higher plant height observed with high fertility condition i.e. $150 \%$ RDF and showed parity with $125 \%$ RDF application, and significantly better to other subplot options. The gradual increase in fertility levels from 50 to 100 and further to $150 \%$ NPK resulted in consistent increase in plant height. Such a response with respect to plant height in soil having low to medium fertility status was quite obvious.

Similar result was also reported by Singh and Ahmed (2008). Mulching practices gave significant response with shoots/plant, and maximum number observed with rice straw mulch and showed parity with the FYM mulching and significantly better to other options. Availability of optimum moisture regimes might have helped to increase number of shoots/plant (Saikia, 2011). Fertility levels gave significant response with shoots/plant, and highest registered with the $125 \%$ RDF and statistically better to other subplot treatments. LAI failed to produce any statistical difference with various mulching practices, however maximum observed with rice straw leaf mulching. Moreover, fertility levels produced significant response and highest LAI observed with $125 \%$ RDF and its showed parity with all the treatments except extreme low level of NPK use i.e. $50 \%$ RDF. 
Number of haulms per plant produced with FYM mulch was at par with rice straw mulch and significantly higher than other treatments. Higher number of haulms per plant in mulch plot might be due to better hydrothermal regimes of soil which might have resulted into better crop growth. These results are in accordance with those of Jalil et al., (2004). Gradual increase in fertility levels from 50 to $125 \%$ NPK increased number of haulms per plant significantly. However the difference between 50 and $75 \%$ NPK and 100 and $150 \%$ NPK was not significant. These results were in accordance with those of Nizamuddin et al., (2003).

\section{Microbial population}

The microbes count was observed to be higher when compared to initial stage of data recording (Table 3). Highest number of bacterial population observed with FYM treated plot and showed parity with all other treatment except no mulch condition. The increase in microbial colonies/population may be due to increasing organic carbon content of the soil due to mulching which is considered as one of the major constituents of the food supply for microorganisms. With fertility levels highest bacterial population registered with the $75 \%$ RDF and statistically better to all other options. Diazotrophs and fungal count more observed with FYM mulching and significantly better to all other main plot treatments. It was observed that microbial population was more in mulched soil than unmulched soil. The increased rhizospheric bacterial population in mulched crops also reported by Tiquia et al., (2002). 125\% RDF registered more diazotrophs count and showed parity only with $100 \%$ RDF, and significantly better to other options. However, fungal count was more observed with $75 \%$ RDF and showed parity with all other treatment except 50 and 150\% RDF. Lastly, PGPRs count was more observed with stubble mulching and was at par only with rice straw mulching. Fertility levels revealed that, higher PGPRs count registered with $125 \%$ RDF and showed parity only with $100 \%$ RDF application. Improve fertilization imposes effect on growth of microbes. The similar findings were reported by Shashidhar et al., (2009).

Table.1 Dry matter production and crop growth rate of potato as influenced by mulching and fertility levels (Pooled data of two years)

\begin{tabular}{|c|c|c|c|c|c|c|c|}
\hline \multirow[t]{3}{*}{ Treatments } & \multicolumn{4}{|c|}{ Dry matter production $\left(\mathrm{g} / \mathrm{m}^{2}\right)$} & \multicolumn{3}{|c|}{ Crop growth rate $\left(\mathrm{g} / \mathrm{m}^{2} /\right.$ day $)$} \\
\hline & 50 & 60 & 70 & 80 & $50-60$ & $60-70$ & $70-80$ \\
\hline & DAP & DAP & DAP & DAP & DAP & DAP & DAP \\
\hline \multicolumn{8}{|c|}{ Mulching practices } \\
\hline No mulch & 198.33 & 258.66 & 341.87 & 450.33 & 6.03 & 8.32 & 10.84 \\
\hline Stubble & 241.08 & 378.11 & 581.66 & 665.63 & 13.70 & 20.35 & 8.39 \\
\hline Rice straw & 322.66 & 416.12 & 602.33 & 811.50 & 9.35 & 18.62 & 20.91 \\
\hline FYM & 221.09 & 331.08 & 544.01 & 740.33 & 10.99 & 21.29 & 19.63 \\
\hline SEm \pm & 4.21 & 5.63 & 7.65 & 8.11 & 0.65 & 1.21 & 0.81 \\
\hline C.D. (0.05) & 13.14 & 16.32 & 21.97 & 23.13 & 1.83 & 3.15 & 2.05 \\
\hline \multicolumn{8}{|c|}{ Fertility levels } \\
\hline $50 \% \mathrm{RDF}$ & 213.33 & 341.17 & 542.17 & 701.75 & 12.784 & 20.11 & 15.95 \\
\hline $75 \% \mathrm{RDF}$ & 235.11 & 505.51 & 601.05 & 758.42 & 27.04 & 9.55 & 15.73 \\
\hline $100 \%$ RDF & 313.55 & 453.36 & 676.11 & 798.33 & 13.981 & 22.27 & 12.22 \\
\hline $125 \% \mathrm{RDF}$ & 298.67 & 512.66 & 715.67 & 891.42 & 21.399 & 20.30 & 17.57 \\
\hline $150 \% \mathrm{RDF}$ & 314.50 & 548.88 & 638.33 & 719.50 & 12.784 & 20.12 & 15.95 \\
\hline SEm \pm & 3.62 & 4.66 & 5.11 & 8.36 & 0.98 & 1.03 & 0.96 \\
\hline C.D. $(0.05)$ & 11.11 & 14.66 & 15.87 & 26.11 & 2.65 & 3.11 & 2.68 \\
\hline
\end{tabular}


Table.2 Effect of mulching and fertility levels on crop growth, yield attributing characters and yield at harvest (Pooled data of two years)

\begin{tabular}{|c|c|c|c|c|c|c|c|c|c|c|c|c|c|c|c|}
\hline \multirow[t]{2}{*}{ Treatment } & \multirow[t]{2}{*}{$\begin{array}{l}\text { Plant } \\
\text { height } \\
(\mathrm{cm})\end{array}$} & \multirow[t]{2}{*}{$\begin{array}{c}\text { Shoots/ } \\
\text { plant } \\
\text { (No.) }\end{array}$} & \multirow[t]{2}{*}{ LAI } & \multirow[t]{2}{*}{$\begin{array}{c}\text { Haulms } \\
\text { /plant } \\
\text { (No.) }\end{array}$} & \multirow{2}{*}{$\begin{array}{c}\text { Total dry } \\
\text { matter } \\
\text { production } \\
\left(\mathrm{g} / \mathrm{m}^{2}\right)\end{array}$} & \multirow[t]{2}{*}{$\begin{array}{l}\text { Tuber } \\
\text { /plants } \\
\text { (No.) }\end{array}$} & \multirow[t]{2}{*}{$\begin{array}{c}\text { Tuber } \\
\text { weight } \\
(\mathrm{g})\end{array}$} & \multicolumn{3}{|c|}{$\begin{array}{c}\text { Tuber yield } \\
\text { (grade wise) } \\
\text { (t/ha) }\end{array}$} & \multirow{2}{*}{$\begin{array}{l}\text { Total } \\
\text { tuber } \\
\text { yield } \\
\text { (t/ha) }\end{array}$} & \multirow[t]{2}{*}{$\begin{array}{l}\text { Haulm } \\
\text { yield } \\
\text { (t/ha) }\end{array}$} & \multirow[t]{2}{*}{$\begin{array}{c}\text { Cost of } \\
\text { cultivation } \\
\text { (₹ ./ha) }\end{array}$} & \multirow[t]{2}{*}{$\begin{array}{c}\text { Net } \\
\text { return } \\
(₹ . / \mathrm{ha})\end{array}$} & \multirow[t]{2}{*}{$\begin{array}{l}\text { B: C } \\
\text { ratio }\end{array}$} \\
\hline & & & & & & & & $\begin{array}{c}\text { Small } \\
\text { size } \\
(<40 \mathrm{~g})\end{array}$ & $\begin{array}{c}\text { Medium } \\
\text { size } \\
(<40 \mathrm{~g})\end{array}$ & $\begin{array}{c}\text { Large } \\
\text { size } \\
(<40 \mathrm{~g})\end{array}$ & & & & & \\
\hline \multicolumn{16}{|c|}{ Mulching practices } \\
\hline No mulch & 44.65 & 3.25 & 2.25 & 3.60 & 601.32 & 5.08 & 32.49 & 3.24 & 9.09 & 11.21 & 23.54 & 1.91 & 43548 & 40879 & 1.94 \\
\hline Stubble & 57.65 & 3.87 & 2.10 & 3.94 & 835.64 & 6.85 & 54.36 & 6.98 & 8.05 & 15.65 & 30.68 & 2.13 & 52365 & 54895 & 2.05 \\
\hline Rice straw & 60.65 & 5.21 & 2.31 & 4.32 & 1056.33 & 7.31 & 60.11 & 4.12 & 9.61 & 17.44 & 31.17 & 2.54 & 56978 & 60512 & 2.06 \\
\hline FYM & 52.35 & 4.68 & 2.14 & 4.45 & 843.65 & 5.84 & 52.91 & 3.02 & 7.98 & 13.44 & 24.44 & 2.55 & 54365 & 52359 & 1.96 \\
\hline $\mathrm{SEm} \pm$ & 2.35 & 0.41 & 0.39 & & 102.36 & 0.42 & 2.51 & 0.37 & 0.41 & 1.21 & 1.89 & 0.05 & & & \\
\hline C.D. $(0.05)$ & 5.11 & 1.32 & NS & 0.34 & 312.65 & 1.25 & 6.04 & 1.06 & 1.14 & 3.12 & 5.02 & 0.14 & & & \\
\hline \multicolumn{16}{|c|}{ Fertility levels } \\
\hline $50 \% \mathrm{RDF}$ & 42.32 & 3.11 & 1.56 & 3.84 & 515.32 & 4.01 & 40.23 & 6.14 & 5.04 & 8.32 & 19.51 & 1.51 & 51245 & 23452 & 1.46 \\
\hline $75 \% \mathrm{RDF}$ & 53.36 & 3.54 & 2.36 & 4.22 & 848.77 & 5.81 & 50.80 & 6.54 & 7.56 & 12.69 & 26.79 & 1.65 & 54879 & 50891 & 1.93 \\
\hline $100 \% \mathrm{RDF}$ & 57.55 & 4.21 & 2.04 & 4.28 & 1145.32 & 5.12 & 55.01 & 5.69 & 9.65 & 14.33 & 29.67 & 2.36 & 57974 & 59875 & 2.03 \\
\hline $125 \% \mathrm{RDF}$ & 61.06 & 5.31 & 2.45 & 4.48 & 1256.32 & 6.31 & 61.98 & 3.32 & 12.11 & 17.65 & 33.08 & 2.58 & 65487 & 70745 & 2.08 \\
\hline $150 \% \mathrm{RDF}$ & 62.35 & 5.19 & 2.37 & 4.26 & 945.32 & 5.79 & 51.36 & 4.36 & 10.65 & 11.65 & 27.66 & 2.04 & 70215 & 65874 & 1.94 \\
\hline $\mathrm{SEm} \pm$ & 1.32 & 0.52 & 0.16 & 0.54 & 124.65 & 0.48 & 2.81 & 0.49 & 1.54 & 1.23 & 1.75 & 0.08 & & & \\
\hline C.D. (0.05) & 4.78 & 1.56 & 0.47 & NS & 366.36 & 1.39 & 7.36 & 1.33 & 4.12 & 3.48 & 4.35 & 0.21 & & & \\
\hline
\end{tabular}


Table.3 Microbial population as influenced by mulching and fertility levels in potato (Pooled data of two years)

\begin{tabular}{|c|c|c|c|c|}
\hline Treatments & $\begin{array}{l}\text { Bacterial population } \\
\left(\mathrm{cfu} / \mathrm{g} \text { of soil } \times 10^{6}\right)\end{array}$ & $\begin{array}{l}\text { Diazotrophs count } \\
\left(\mathrm{cfu} / \mathrm{g} \text { of soil } \times 10^{5}\right)\end{array}$ & $\begin{array}{c}\text { Fungal count } \\
\left(\mathrm{cfu} / \mathrm{g} \text { of soil } \mathrm{x} 10^{3}\right)\end{array}$ & $\begin{array}{c}\text { PGPRs count } \\
\left(\mathrm{cfu} / \mathrm{g} \text { of soil } \times 10^{5}\right)\end{array}$ \\
\hline \multicolumn{5}{|c|}{ Mulching practices } \\
\hline No mulch & 7.33 & 8.06 & 11.87 & 3.06 \\
\hline Stubble & 11.08 & 12.11 & 16.36 & 16.63 \\
\hline Rice straw & 10.66 & 16.12 & 14.33 & 11.11 \\
\hline FYM & 12.09 & 21.08 & 22.45 & 8.46 \\
\hline SEm \pm & 1.21 & 5.63 & 1.82 & 2.25 \\
\hline C.D. (0.05) & 3.14 & 16.32 & 4.07 & 7.18 \\
\hline \multicolumn{5}{|c|}{ Fertility levels } \\
\hline $50 \% \mathrm{RDF}$ & 13.33 & 3.32 & 12.07 & 11.32 \\
\hline $75 \% \mathrm{RDF}$ & 25.11 & 19.25 & 21.05 & 8.54 \\
\hline $100 \% \mathrm{RDF}$ & 14.55 & 21.06 & 16.11 & 20.33 \\
\hline $125 \% \mathrm{RDF}$ & 14.67 & 23.69 & 18.67 & 21.42 \\
\hline $150 \% \mathrm{RDF}$ & 11.50 & 17.88 & 14.11 & 13.50 \\
\hline $\mathrm{SEm} \pm$ & 3.62 & 1.16 & 2.11 & 2.16 \\
\hline C.D. (0.05) & 11.11 & 3.66 & 5.21 & 6.44 \\
\hline
\end{tabular}

\section{Growth parameters}

Plant experiencing no moisture conservation practices i.e no mulch resulted in poor dry matter accumulation which might be attributed to reduced plant height, reduced leaves and leaf size as compared to mulch condition. Rice straw mulch produced significantly more dry matter production and was at par with all other main plot treatments except no mulch condition. $125 \%$ RDF produced more total dry matter $\left(\mathrm{g} / \mathrm{m}^{2}\right)$ and was comparable with 100 and $150 \%$ RDF and notably better to other NPK levels. Data presented in Table 1 revealed that average number of tubers produced per plant under rice straw mulch was much higher compared to all other main plots treatment, and was comparable only with stubble mulch practices. This corroborate with the findings of Jalil et al., (2004). In case of fertility levels, application of $125 \%$ of the recommended NPK recorded significantly highest average number of tubers per plant and showed parity with all the treatments except 50\% RDF. These results are in accordance with those of Nizamuddin et al., (2003). Mulching and fertility levels showed significant effect on average weight of tuber per plant. Significantly maximum weight of tubers per plant was obtained with rice straw mulch followed by stubble mulching, and showed parity amongst themselves. However lowest average weight of tuber observed with no mulch and was followed by FYM mulch practices.

These results were in conformity with the findings of Uniyal and Mishra (2003). Highest weight of tuber was recorded with $125 \%$ NPK and showed parity with $100 \%$ RDF and statistically better to all other options. Gradual increase in fertility levels from 50 to $125 \%$ of the recommended NPK resulted in increase of average weight of tubers per plant consistently. This consistent increase with increase in fertility level over the preceding level could be attributed to the enhanced growth of plant due to improvement in nutrition of crop. 


\section{Tuber yield}

Grade wise tuber yield as depicted in Table 2 was markedly influenced by different main and sub plot treatments. Production of small size tuber was more observed with stubble mulch and least found with FYM treated plots. Medium size tuber production more found with the rice straw mulch, and was statistically better to all other mulching practices. Maximum production of large size potato tuber observed with the rice straw mulch and showed party only with stubble mulching practices and significantly better to other main plot treatments. Further table revealed that, with various fertility levels least small size tuber observed with the $125 \%$ RDF and showed parity with $150 \%$ RDF combinations. Moreover, medium and large size tuber production maximum observed with the $125 \%$ RDF and its showed parity with all the treatments except 50,75\% RDF and $150 \%$ RDF. From the above context, it is clear cut depict that tuber production largely influenced by nutrient availability inside the soil (Mukheree, 2017). With various main plot treatments, mulches application produced significant response amongst different plots. Use of rice straw mulch, recorded the highest tuber yield $(31.17 \mathrm{t} / \mathrm{ha})$ though it remained statistically at par with stubble mulching practices $(30.68 \mathrm{t} / \mathrm{ha})$, and significantly better to all other treatments. No mulch registered the lowest yield $(23.54 \mathrm{t} / \mathrm{ha})$ and showed parity with FYM mulch treatment (Table 2). The increasing levels of fertilizer levels from 50 to $125 \%$ RDF, gradually and significantly increased the yield. The maximum yield $(33.08 \mathrm{t} / \mathrm{ha})$ was registered with $125 \% \mathrm{RDF}$ that remained statistically at par only with 100 $\%$ RDF and significantly better to other subplot treatments. Perhaps fertilization of more nutrients with $125 \%$ RDF was conducive to enhance metabolic activities within the plant, bringing about better growth and development, particularly in the number and size of tubers and ultimately more yields.
This corroborate with the finding of Somani et al., (2002). Further, table 2 revealed that, use of high levels of fertilizer i.e. $150 \%$ RDF showed poor performance on yield might be due to higher nitrogen levels resulted in succulent, vegetative growth and delayed maturity thus making the plant more susceptible to disease. Similar kind of observation reported by Agrios (1998).

\section{Economics}

Production economics is the ultimate target of any study for is acceptability to the common beneficiary group of farming community either small or marginal considering its economic viability in the regions. In the study, system productivity corresponding to its benefit over subtracting the cost for production was calculated in terms of net return expressed in ₹/ha and ultimately benefit: cost ratio of system (Table 2). Economics revealed that, higher $\mathrm{B}: \mathrm{C}$ ratio (2.06) and net return (₹ 60,512/ha) found with rice straw mulching and was followed by stubble mulching. Further with fertility levels maximum B:C ratio (2.07) and net return (₹ $70,475 / \mathrm{ha}$ ) found with $125 \% \mathrm{RDF}$ and it was very close to $100 \% \mathrm{RDF}$. These finding opined that more favorable soil environment manifested in higher yields makes mulching not only soil protective but economically favorable also.

The result lead to conclusion that for realizing higher tuber yield and improve microbial population in soil ecosystem, it should planted with rice mulch along with $125 \% \mathrm{RDF}$ as the said combination recorded the higher tuber production and net return with maximum benefit: cost ratio.

\section{References}

Agrios, G.N., 1988. Environmental effects on infectious plant disease development. In: Plant Pathology ( $3^{\text {rd }}$ edition). Academic 
Press Inc, California, pp 803.

Aguero, M.V., Ponce, A.G., Moreira, M.R. and Roura, S.I. 2008. Plastic mulch improves microbial quality and shelf life of cold stored butter lettuce (Lactuca sativa var. Lores). Fresh Produce, 2: 6-13.

Jackson, M.L. 1973. Soil Chemical Analysis Prentice Hall India Pvt. Ltd., New Delhi.

Jalil, M.A., Azad, M.A.K. and Farooqu, A.M. 2004. Effect of different mulches on the growth and yield of two potato varieties. Journal of Biological Sciences, 4(3):331333.

Mikkelsen R., 2006. Best management practices for profitable fertilization of potatoes. Better Crops, 90 (2)-65.

Mukherjee, Dhiman 2015. Microbial diversity for soil sustainability and crop productivity. In Microbial empowerment in Agriculture: A key to sustainability and crop productivity (eds. Birichi Kumar Sharam and Akanksha Singh). Biotech publishers, New Delhi. 237-268.

Mukherjee, Dhiman. 2017. Improved agronomic practices and input use efficiency for potato production under changing climate. In : Sustainable potato production and the impact of climate change. (Eds, Londhe, Sunil), IGI Global (DOI : 10.4018/978-15225-1715-3ch005). pp105-132.

Nizamuddin, M., Mahmood, M., Farooq, K. and Riaz, S. 2003. Response of potato crop to various levels of NPK. Asian Journal of Plant Sciences, 2(2): 149-151.

Panse, V. G., and Sukhatme, P.V. 1995. Statistical Methods for Agricultural Workers, ICAR, New Delhi.pp. 342-343.

Ponce, A.G., Aguero, M.V., Rowa. S.I., Del Valle, C.E. and Moreira, M.R. 2008. Dynamics of indigenous microbial populations of butter head lettuce grown in mulch and on bare. Food Science Research Journal, 73: 257-63.
Saikia, M., 2011. Effect of irrigation and mulching on growth, yield and water use efficiency of potato in Assam. Potato Journal, 38 (1): 81-83.

Shashidhar, K. R., Bhaskar, R.N., Priyadharshini, P. and Chandrakumar, H. L. 2009. Effect of different organic mulches on $\mathrm{pH}$, organic carbon content and microbial status of soil and its influence on leaf yield of M5 mulberry (Morus indica L.) under rainfed condition. Current Biotica, 2: 405-12.

Singh, N., and Ahmed, Z. 2008. Effect of mulching on potato production in high altitude cold and arid zone of Ladakh. Potato Journal, 35(3-4):118-121.

Somani, A.K., Kushwah, V.S. and Singh, S.P. 2002. Management of stem necrosis disease in early planted potato crop with varying fertilizer levels. Journal of Indian Potato Association, 29(3-4): 301-303.

Tiquia, S.M., Wan, J.H.C and Tam, N.F.Y. 2002. Microbial population dynamics and enzyme activities during composting. Compost Science \& Utilisation, 10: 150-61.

Uniyal, S.P., and Mishra, A.C. 2003. Response of potato to soil moisture and temperature as affected by different mulches.

Wright, L., and Hedley, D.1933. The importance of adequate reduction of peptone in the preparation of media for the pneumococcus and other organisms. Journal of Pathology and Bacteriology, 37: 257-82.

Zahir, Z.A., Arshad M, Frankenberger W.T. 2004. Plant growth promoting rhizobacteria: applications and perspectives in agriculture. Advances in Agronomy, 81: 97-168.

Zebarth, B.J., Rosen C.J. 2007. Research perspective on nitrogen BMP development for potato. American Journal of Potato Research, 84: 3-18.

\section{How to cite this article:}

Dhiman Mukherjee. 2017. Influence of Mulching and Graded Fertility Levels on Microbial Population, Growth and Productivity of Potato (Solanum tuberosum L.). Int.J.Curr.Microbiol.App.Sci. 6(10): 4784-4792. doi: https://doi.org/10.20546/ijcmas.2017.610.445 